\title{
PENGARUH ADVERSITY QUOTIENT (AQ) DAN KEMAMPUAN BERPIKIR KRITIS TERHADAP PRESTASI BELAJAR MATEMATIKA
}

\author{
Leonard dan Niky Amanah \\ e-mail: leonard@unindra.ac.id \\ Jurusan Pendidikan Matematika, Universitas Indraprasta PGRI
}

\begin{abstract}
Abstrak: Penelitian ini bertujuan untuk menganalisis pengaruh Adversity Quotient (AQ) dan kemampuan berpikir kritis terhadap prestasi belajar matematika. Penelitian ini adalah penelitian survei korelasional, dengan populasi siswa kelas VIII SMPN 251 Jakarta yang dilaksanakan pada bulan Maret hingga Juli 2013. Sampel diambil dengan teknik simple random sampling sejumlah 57 siswa. Instrumen yang digunakan adalah angket dan dokumentasi. Analisis data menggunakan analisis regresi berganda. Berdasarkan hasil perhitungan diperoleh terdapat pengaruh positif Adversity Quotient (AQ) dan kemampuan berpikir kritis secara bersama-sama terhadap prestasi belajar matematika; terdapat pengaruh positif Adversity Quotient (AQ) terhadap prestasi belajar Matematika; dan terdapat pengaruh positif kemampuan berpikir kritis terhadap prestasi belajar Matematika.
\end{abstract}

Kata-kata kunci: adversity quotient, kemampuan berpikir kritis, prestasi belajar, matematika

\section{EFFECT OF ADVERSITY QUOTIENT AND CRITICAL THINKING ABILITY TOWARDS LEARNING ACHIEVEMENT IN MATHEMATICS}

\begin{abstract}
This research aimed at analyzing the impact of the Adversity Quotient (AQ) and critical thinking ability on mathematics learning achievement. This is a correlational survey research design, with population was the student 8th grade in SMPN 251 Jakarta, and was done from March until July 2014. Study sample is 57 students were drawn from a population with simple random sampling technique. The instruments were in the forms of questionnaires and documentation. The data were analyzed using multiple regressions. The result showed: Adversity Quotient (AQ) and critical thinking abilities had positive and significant simultaneous impact on mathematics learning achievement; adversity quotient had a positive and significant impact on mathematics learning achievement; critical thinking ability had a positive and significant impact on mathematics learning achievement.
\end{abstract}

Keywords: adversity quotient, critical thinking ability, learning achievement, mathematic

\section{PENDAHULUAN}

Era globalisasi berkembang demikian cepat yang ditandai dengan semakin berkembangnya teknologi yang serba canggih. Agar tidak tertinggal oleh pesatnya persaingan, maka setiap siswa harus memiliki pengetahuan dan kemampuan berpikir yang selalu meningkat. Untuk memperoleh pengetahuan dan meningkatkan kemampuan berpikir, salah satu cara yang ditempuh adalah dengan meningkatkan mutu pendidikan. Proses pendidikan merupakan interaksi antara guru dan siswa yang disebut proses belajar mengajar. Siswa yang mengalami proses belajar, maka akan terjadi perubahan. Untuk mengetahui seberapa besar perubahan tersebut, perlu diadakan penilaian. Nilai yang dicapai sebagai hasil dari proses belajar dinamakan prestasi belajar. Prestasi belajar tidak hanya dipengaruhi oleh interaksi guru dan siswa saja, tetapi juga ada faktor lain yang mempengaruhi, yaitu faktor dari dalam diri siswa (faktor internal) dan faktor dari luar diri siswa (faktor eksternal).

Kecerdasan atau intelegensi merupakan salah satu faktor internal yang digolongkan ke dalam faktor psikologis yang memengaruhi prestasi belajar siswa. Ada cukup banyak jenis kecerdasan yang dimiliki siswa, salah satunya adalah Adversity Quotient (AQ). Adversity quotient merupakan kecerdasan yang mampu mengubah hambatan menjadi peluang. Kecerdasan ini berbicara tentang bagaimana cara pandang manusia tersebut memandang sebuah kesulitan dan cara mere-ka keluar dari kesulitan yang dihadapi. Dari hal tersebut dapat dikatakan bahwa setiap manusia memiliki kecerdasan adversity yang berbeda-beda. Stoltz (Fauziyah, dkk, 2013: 78) mengelompokkan manusia dalam tiga kategori $\mathrm{AQ}$, yaitu: quitter ( $\mathrm{AQ}$ rendah), 
camper (AQ sedang), dan climber (AQ tinggi). Quitters merupakan kelompok manusia yang kurang memiliki kemauan untuk menerima tantangan dalam hidupnya. Campers merupakan kelompok manusia yang sudah memiliki kemauan untuk berusaha menghadapi masalah dan tantangan yang ada, tetapi mereka berhenti karena merasa sudah tidak mampu lagi. Berikutnya, Climbers merupakan kelompok manusia yang memilih untuk terus bertahan untuk berjuang menghadapi berbagai macam hal yang akan terus menerjang, baik berupa masalah, tantangan, hambatan, maupun halhal lain yang terus didapat setiap harinya.

Selain kecerdasan adversity, kemampuan berpikir kritis juga salah satu faktor yang mendukung prestasi belajar. Banyak pihak mengatakan bahwa salah satu ciri orang pintar adalah mampu berpikir kritis. Akan tetapi, jika diperhatikan, dalam pembelajaran siswa kurang didorong mengembangkan kemampuan berpikirnya. Pembelajaran hanya diarahkan untuk menghapal dan menimbun informasi, sehingga siswa pintar secara teoretis, tetapi miskin aplikasi. Akibatnya, kemampuan berpikir kritis menjadi beku bahkan menjadi susah untuk dikembangkan. Di sekolah, kebanyakan siswa cenderung pasif. Bahkan, apabila guru melemparkan pertanyaan, semua siswa cenderung terdiam. Hal ini menunjukkan bahwa dalam kegiatan pembelajaran sebagian siswa semakin kehilangan kekritisannya. Leonard (2013: 56) menegaskan bahwa pada dasarnya setiap tindakan yang dilakukan oleh manusia merupakan buah dari berpikir, tetapi tidak semua manusia ingin menggunakan otaknya untuk berpikir hal-hal yang baik. Dapat dikatakan, jika siswa pasif dalam belajar, hal tersebut merupakan buah dari ketidakmampuan siswa dalam mendayagunakan potensi berpikirnya.

Dalam standar isi untuk satuan pendidikan dasar dan menengah mata pelajaran matematika (Peraturan Menteri Pendidikan Nasional Nomor 22 Tahun 2006 tanggal 23 Mei 2006 tentang Standar Isi) telah disebutkan bahwa "mata pelajaran Matematika perlu diberikan kepada semua peserta didik mulai dari sekolah dasar untuk membekali peserta didik dengan kemampuan berpikir logis, analitis, sistematis, kritis, dan kreatif, serta kemampuan bekerja sama". Mengembangkan kemampuan berpikir logis, analitis, sistematis, kritis maupun bekerja sama sudah lama menjadi fokus dan perhatian pendidik Matematika di kelas, karena hal itu berkaitan dengan sifat dan karakteristik keilmuan Matematika.

Matematika merupakan salah satu mata pelajaran yang penting di sekolah dan diujikan dalam Ujian Nasional, serta sebagai salah satu faktor penentu lulus atau tidaknya siswa dalam suatu jenjang pendidikan formal. Pentingnya matematika juga diungkapkan oleh Leonard (2012: 11) yang mengatakan bahwa "mathematics has an important role for the development of science, and to learn mathematic, we must thinking". Namun, sayangnya matematika masih dianggap sebagai mata pelajaran sulit dan menakutkan. Bahkan, sebagian besar siswa membenci mata pelajaran Matematika.

Pemecahan soal-soal matematika memang agak rumit atau dituntut kreativitas dan berpikir menggunakan logika yang cukup dalam, sehingga penting bagi siswa untuk menggali kemampuannya serta berlatih. Akan tetapi, kenyataan di lapangan, banyak siswa yang mudah menyerah dan bahkan tidak bersemangat menggunakan kemampuan otaknya untuk berpikir dan menyelesaikan setiap masalah yang dihadapi dalam pelajaran ini. Hal ini tentunya berkaitan erat dengan kekuatan mental dan ketahanan siswa menghadapi masalah, artinya, jika siswa memiliki kecerdasan adversity yang tinggi, mereka akan mampu menghadapi dan memecahkan permasalahannya. Akan tetapi sebaliknya, siswa yang memiliki kecerdasan adversity yang rendah, akan lebih mudah menyerah menghadapi masalah yang dihadapi. Kondisi ini perlu mendapat perhatian yang cukup besar, sehingga nantinya dapat memperbaiki kualitas pendidikan di Indonesia, khususnya dalam pembelajaran matematika.

\section{Hakikat Prestasi Belajar Matematika}

Manusia dibekali akal dan pikiran agar mereka mampu membedakan mana yang benar dan mana yang salah. Untuk mengetahui itu diperlukan suatu pengetahuan dan pengalaman. Untuk memperoleh pengetahuan dan pengalaman diperlukan suatu proses yang dinamakan belajar. Belajar secara umum merupakan kegiatan yang selalu dilakukan oleh seorang manusia selama hidupnya. Manusia belajar untuk hidup dan hidup untuk belajar. Itu artinya, kegiatan belajar adalah kegiatan seumur hidup yang dilakukan manusia dalam rangka memperkaya dan meningkatkan pengetahuannya. Belajar merupakan serangkaian proses yang aktif. Subini (2011: 11) mengatakan bahwa "pengertian belajar tidak cukup hanya dengan duduk diam, mendengarkan apa yang diajarkan guru, mencatat, kemudian mengerjakan soal evaluasi dan mendapatkan nilai. Belajar merupakan sebuah proses mengobservasi, mendengar, membaca, meniru, mencoba berbuat sesuatu dan meniru perintah", sehingga dapat dikatakan bahwa belajar merupakan suatu proses aktif untuk meniru apa yang dicontohkan. Leonard dan Kiki (2009: 85) mengatakan 
bahwa "belajar adalah kegiatan yang berhubungan dengan perubahan tingkah laku manusia, yang diakibatkan oleh pengalaman". Dengan kata lain, belajar merupakan proses yang mengakibatkan perubahan setelah aktivitas yang dilakukan oleh siswa, yaitu proses pembelajaran.

Sejalan dengan hal tersebut, Sardiman (2011: 20) juga mengatakan bahwa "belajar itu senantiasa merupakan perubahan tingkah laku atau penampilan, dengan serangkaian kegiatan misalnya dengan membaca, mengamati, mendengarkan, meniru dan lain sebagainya". Dapat disimpulkan bahwa belajar adalah serangkaian kegiatan yang akan menghasilkan perubahan tingkah laku. Perubahan tingkah laku yang dimaksud merupakan perubahan ke arah yang lebih baik, bahkan belajar akan menghasilkan kemampuan manusia untuk menyesuaikan diri dengan lingkungannya. Terjadinya perubahan tingkah laku tersebut sebagai pengaruh dari pengetahuan dan keterampilan yang didapatkan selama proses belajar berlangsung. Contohnya adanya perubahan dari tidak tahu menjadi tahu setelah memperoleh ilmu pengetahuan dan keterampilan serta diharapkan akan menguasai ilmu pengetahuan tersebut. Dengan ilmu pengetahuan dan keterampilan yang dimiliki, siswa diharapkan dapat mengaplikasikannya dalam kehidupan sehari-hari.

Kata prestasi dan belajar merupakan kata yang sulit untuk dipisahkan karena banyak anggapan yang berasumsi bahwa belajar merupakan suatu proses, sedangkan prestasi belajar merupakan hasil dari proses pembelajaran tersebut. Menurut Arifin (2009: 12) "prestasi belajar merupakan suatu masalah yang bersifat perenial dalam sejarah kehidupan manusia, karena sepanjang rentang kehidupannya manusia selalu mengejar prestasi menurut bidang dan kemampuan masing-masing", sehingga dapat dikatakan bahwa prestasi merupakan hasil usaha yang akan selalu dikejar manusia. Lebih lanjut, Sagitasari (2010: 37) mengatakan bahwa "prestasi belajar merupakan taraf keberhasilan sebuah proses mengajar belajar (the teaching-learning process) yang dicapai oleh seseorang setelah melakukan kegiatan belajar dan dinyatakan dalam rapor". Prestasi belajar ditunjukkan dengan skor atau angka yang menunjukkan nilai-nilai dari sejumlah mata pelajaran yang menggambarkan pengetahuan dan keterampilan yang diperoleh siswa, serta untuk dapat memperoleh nilai digunakan tes terhadap mata pelajaran terlebih dahulu. Hasil tes inilah yang menunjukkan keadaan tinggi rendahnya prestasi yang dicapai oleh siswa. Seorang siswa dikatakan berprestasi apabila ia sudah mencapai atau bahkan melebihi standar-standar yang telah dibuat. Winkel (1999: 146) mengatakan bahwa "prestasi belajar adalah suatu bukti keberhasilan belajar atau kemampuan seseorang siswa dalam melakukan kegiatan belajarnya sesuai dengan bobot yang dicapainya". Berdasarkan pendapat di atas dapat disimpulkan bahwa prestasi belajar adalah bukti keberhasilan belajar siswa di sekolah berupa kecakapan dan kemampuan yang dicatat dalam bukti laporan.

Matematika memiliki peranan yang penting bagi perkembangan ilmu pengetahuan. Kemajuan yang pesat dalam bidang ilmu lain tidak terlepas dari peran Matematika yang merupakan sebuah ilmu dasar. Ilmu ini bahkan sudah ditanamkan sejak usia dini hingga jenjang perguruan tinggi. Ilmu ini penting karena sangat bermanfaat untuk kehidupan. Manusia sulit untuk terlepas dari Matematika, karena dalam kehidupan sehari-hari ilmu ini selalu dipakai. Di pasar, di kantor, di bank, di pusat perbelanjaan, di mana-mana ilmu ini selalu dipakai. Suriasumantri (2005: 193) mengatakan bahwa, "matematika mempunyai kelebihan lain dibandingkan dengan bahasa verbal. Matematika mengembangkan bahasa numerik yang memungkinkan kita melakukan pengukuran secara kuantitatif". Sebagai contoh, bahasa verbal hanya mampu mengatakan bahwa objek A lebih besar, lebih tinggi, lebih kecil dari objek B, tetapi bahasa verbal tidak dapat mengukur perbandingan antara objek $\mathrm{A}$ dan objek B sedangkan matematika dapat mengukur perbandingan antara objek A dan objek B. Lebih jauh Suriasumantri (2005: 193) mengatakan, "bahasa verbal hanya mampu mengemukakan pernyataan yang bersifat kualitatif".

Matematika sebetulnya tidak hanya bicara angka atau bilangan semata, melainkan juga bicara tentang konsep, gagasan, ide, pola-pola bentuk dan sistem penalaran yang menyebabkan orang menjadi bertambah cerdas. Matematika dapat dianalogikan, bila senam kesegaran jasmani merupakan olahraga yang menjadikan orang akan sehat badannya, sedangkan Matematika merupakan "senam otak", sehingga orang akan cerdas atau sehat penalarannya. Hal ini senada dengan pendapat Nasution (1980: 12) yang mengatakan, "bahwa dengan menguasai Matematika orang akan mengatur jalan pemikirannya dan sekaligus belajar menambah kepandaiannya". Matematika pada dasarnya adalah pengetahuan yang disusun secara konsisten dan berdasarkan logika deduktif. Mempelajari matematika berarti berlatih mengatur dan mengarahkan jalan pemikiran seseorang pada alur pemikiran yang logis. Sehingga dapat disimpulkan 
bahwa yang dimaksud dengan matematika adalah ilmu yang mempelajari tentang cara penalaran logis berupa ide/konsep abstrak yang tersusun secara hirarkis yang diwujudkan dalam bentuk simbol-simbol serta penalarannya bersifat deduktif.

Prestasi belajar dalam lingkungan sekolah dipahami sebagai hasil nilai atau angka yang diberikan oleh guru pada siswa berdasarkan penguasaan. Atau keterampilan yang dimiliki siswa melalui evaluasi belajar yang dilakukan. Matematika sebagai salah satu pelajaran yang diberikan berdasarkan kurikulum yang telah dicapai menuntut banyak potensi dan usaha siswa didalamnya agar mampu mencapai prestasi atau hasil yang optimal. Oleh karena itu, prestasi belajar Matematika dapat diartikan sebagai hasil dari proses pembelajaran Matematika berupa nilai yang diberikan oleh guru kepada siswa berdasarkan kecakapan dan kemampuan yang dimiliki siswa melalui evaluasi belajar yang dilakukan dan dicatat dalam bukti laporan.

\section{Hakikat Adversity Quotient ( $A Q$ )}

Setiap orang pasti memimpikan sebuah kesuksesan. Akan tetapi dalam mencapai kesuksesan itu sendiri butuh perjuangan yang tidak mudah, pasti akan selalu ada cobaan, rintangan maupun kesulitan yang menghadang. Menurut Stoltz dan sekaligus pelopor study $A Q$ ini (Hans, 2006: 91) "Adversity Quotient adalah kegigihan dalam mengatasi segala rintangan dalam mendaki puncak sukses yang diinginkan". Sehingga untuk mencapai suatu kesuksesan dibutuhkan Adversity Quotient. Hal ini juga selaras dengan pendapat Agustian (2001: 373), “Adversity Quotient adalah kecerdasan yang dimiliki seseorang dalam mengatasi kesulitan dan bertahan hidup". Hal tersebut diperkuat kembali oleh Ginanjar (Ekasari dan Hafizhoh, 2009: 116) menyatakan “dengan Adversity Quotient seseorang bagai diukur kemampuannya dalam mengatasi setiap persoalan hidup untuk tidak berputus asa". Secara sederhana Adversity Quotient dapat didefinisikan sebagai kecerdasan individu dalam menghadapi kesulitankesulitan, hambatan-hambatan maupun tantangan dalam hidup.

Adversity Quotient bukan hanya kemampuan individu dalam mengatasi sebuah kesulitan yang ada, akan tetapi individu tersebut juga diharapkan dapat mengubah pandangannya akan sebuah kesulitan sebagai sebuah peluang baru untuk mencapai kesuksesan yang dinginkan. Hal ini mungkin dipandang sebagai hal yang sulit bahkan hal yang mustahil oleh banyak orang. Akan tetapi dengan kemampuan Adversity Quotient yang dimiliki setiap individu diharapkan dapat memaksimalkan hal tersebut. Surekha (Wijaya,
2007: 121) mengungkapkan "Adversity Quotient adalah kemampuan berpikir, mengelola dan mengarahkan tindakan yang membentuk suatu pola-pola tanggapan kognitif dan perilaku atas stimulus peristiwa-peristiwa dalam kehidupan yang merupakan tantangan atau kesulitan sebagai peluang. Di tambahkan pula bahwa kesulitan yang dihadapi itu mempunyai beragam variasi bentuk dan kekuatan dari sebuah tragedi yang besar sampai kelalaian kecil". Adversity Quotient dipandang sebagai kecerdasan individu yang mampu meramalkan kemampuan dalam bertahan menghadapi kesulitan serta cara mengatasinya, kesanggupan seseorang bertahan dalam menjalani hidup. Pada dasarnya kecerdasan individu pada setiap orang berbeda-beda, tingkat kemampuan inilah yang berdampak pada kemampuan seseorang dalam kesanggupannya menjalani kehidupan ini. Garmezy dan Michael (Pranandari, 2008: 124) mengutarakan "saat kita dihadapkan pada kesulitan hidup, sebagian individu gagal dan tidak mampu bertahan dimana mereka mengembangkan pola-pola perilaku yang bermasalah. Sebagian lainnya bisa bertahan dan mengembangkan perilaku yang adaptif, bahkan lebih baik lagi bila mereka bisa berhasil keluar dari kesulitan dan menjalani kehidupan yang sehat". Hal ini sesuai dengan pendapat Stoltz (Rahastyana dan Rahman, 2007: 57), "Adversity Quotient mempunyai fungsi untuk meramalkan, antara lain: (a) memberi tahu seberapa jauh seseorang dapat bertahan menghadapi kesulitan dan kemampuan kita untuk mengatasinya, (b) meramalkan siapa yang mampu mengatasi kesulitan dan siap yang akan hancur, (c) meramalkan siapa yang akan melampaui harapan-harapan atas kinerja dan potensi mereka serta siapa yang akan gagal, dan (d) meramalkan siapa yang akan menyerah dan siapa yang akan bertahan".

Dalam arti yang luas, Adversity Quotient merupakan keinginan seseorang untuk meraih sebuah kesuksesan, ketahanan seseorang, kemampuan untuk bangkit serta tidak terhalangi dalam setiap usahanya. Di dalam Adversity Quotient menunjukkan daya tahan, daya bangkit, serta sikap pantang menyerah seseorang. Greenberg (2006: 25) menyatakan "Adversity Quotient is the will you succeed, your resilience, the ability to bounce back, not be deterred in your quest". Kemampuan seseorang bertahan dalam kesulitan hidup sebenarnya disadari atau tidak merupakan manfaat yang ditimbulkan dari Adversity Quotient itu sendiri. Setiap individu memiliki Adversity Quotient yang ada pada dirinya. Jadi, seseorang yang memiliki Adversity Quotient baik akan mampu menghadapi setiap kesulitan yang ada. Sementara sebaliknya 
seseorang yang memiliki Adversity Quotient yang kurang baik akan mengalami kesulitan besar atas masalah yang dihadapinya.

Dari penjelasan di atas dapat disimpulkan bahwa, Adversity Quotient ( $A Q$ ) merupakan kemampuan individu dalam menundukkan tantangantantangan, mampu menekuk kesulitan-kesulitan, serta meringkus masalah-masalah yang menghadang bahkan mampu menjadikannya sebuah peluang dalam menggapai kesuksesan yang diinginkan, sehingga menjadikannya individu yang memiliki kualitas yang baik. Individu yang memiliki Adversity Quotient tinggi akan mempunyai tingkat kendali yang kuat atas peristiwa-peristiwa yang buruk. Kendali yang tinggi akan memiliki implikasi-implikasi yang jangkauannya jauh dan positif, serta sangat bermanfaat untuk kinerja, dan produktivitas. Adversity Quotient yang tinggi mengajar orang untuk meningkatkan rasa tanggung jawab sebagai salah satu cara memperluas kendali, pemberdayaan dan motivasi dalam mengambil tindakan.

\section{Hakikat Kemampuan Berpikir Kritis}

Kemampuan berasal dari kata mampu yang berarti sanggup atau bisa. Seseorang dikatakan mampu apabila ia telah sanggup melakukan suatu tindakan atau sesuatu. Kemampuan setiap manusia berbedabeda, sehingga dengan kemampuan yang dimilikinya seseorang dapat mengoptimalkan potensi yang ada di dalam dirinya. Kemampuan seseorang bukan hanya berbentuk keterampilan saja, melainkan dapat juga terlihat dalam belajar, bergaul, dan bersosialisasi dengan lingkungan masyarakat. Setiap manusia pasti memiliki kemampuan berpikir. Menurut De Bono (1992: 36) "berpikir adalah eksplorasi pengalaman yang dilakukan secara sadar dalam mencapai suatu tujuan". Tujuan itu mungkin berbentuk pemahaman, pengambilan keputusan, perencanaan, pemecahan masalah, penilaian, tindakan, dan sebagainya. Sebagai manusia yang memiliki akal budi maka dalam bertindak dan dalam memutuskan suatu hal haruslah melalui proses berpikir. Karena dengan berpikir, maka akan didapat hasil yang optimal. Menurut Madhi (2009) “Berpikir adalah kerja akal yang dimulai dari sesuatu yang sudah diketahui dan diakhiri dengan penemuan sesuatu yang belum diketahui". Penemuan yang dihasilkan dari suatu proses yang dinamakan berpikir pasti akan sangat berguna bagi manusia yang menjalani kehidupan. Hal yang sama juga diungkapkan oleh Sutarmo (2012: 93) bahwa "Beberapa ahli mendefinisikan berpikir sebagai kemampuan membuat ide atau memperbarui ide". Ide merupakan hasil yang diperoleh dari kemampuan berpikir seorang manusia. Disebut ide karena belum pernah ada yang memikirkan atau mengetahui suatu ide tersebut.

Setiap manusia pasti pernah mengalami suatu masalah yang harus dihadapi dan menuntut penyelesaian. Tidak ada masalah yang tidak dapat diselesaikan. Semua tergantung dari bagaimana cara manusia tersebut menyelesaikannya, namun untuk menyelesaikan masalah tersebut agar tidak salah mengambil langkah, maka dianjurkan untuk berpikir terlebih dahulu secara matang. Berpikir memiliki banyak manfaat, salah satunya yaitu untuk mengambil keputusan dan menyelesaikan masalah. Hassoubah (2009: 43) menggambarkan diagram dimensi berpikir sebagai berikut:

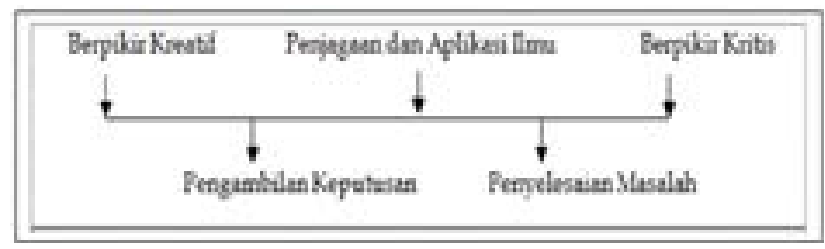

Gambar 1. Diagram dimensi berpikir

Menurut Hassoubah (2009: 44) "pada kenyataannya kita ingat bahwa tiga jenis proses berpikir tersebut yaitu berpikir kreatif, menjaga, dan mengaplikasikan ilmu pengetahuan dan berpikir kritis sangat penting untuk mengembangkan kemampuan berpikir lainnya, yakni membuat keputusan dan menyelesaikan masalah". sehingga dapat diketahui bahwa berpikir sangat diperlukan untuk mengambil keputusan dan menyelesaikan masalah.

Berpikir kritis telah menjadi salah satu tujuan pendidikan saat ini. Berbagai penelitian dan pendapat tentang berpikir kritis telah menjadi topik pembicaraan dalam sepuluh dekade ini. Menurut Syahbana (2012: 46) dinyatakan berikut: "berpikir kritis, sangat diperlukan bagi kehidupan mereka, agar mereka mampu menyaring informasi, memilih layak atau tidaknya suatu kebutuhan, mempertanyakan kebenaran yang terkadang dibaluti kebohongan, dan segala hal yang dapat saja membahayakan kehidupan mereka". sehingga pentingnya berpikir kritis bagi para siswa selaku generasi penerus bangsa agar mereka dapat mengantisipasi bahaya yang membahayakan kehidupan mereka, bangsa, dan negara.

Berpikir kritis merupakan salah satu kemampuan berpikir tingkat tinggi seperti apa yang disebutkan oleh Apriani (2012: 816) bahwa "berpikir kritis merupakan salah satu proses berpikir tingkat tinggi yang dapat digunakan dalam pembentukan sistem konseptual siswa". Sehingga berpikir kritis akan 
sangat membantu siswa dalam proses belajar dan memahami konsep yang baru diterimanya. Dalam proses belajar siswa dituntut untuk mengetahui beragam konsep. Syah (2010: 118) menjelaskan bahwa "dalam hal berpikir kritis, siswa dituntut menggunakan strategi kognitif tertentu yang tepat untuk menguji keandalan gagasan pemecahan masalah dan mengatasi kesalahan atau kekurangan". Jadi dalam berpikir kritis diperlukan strategi yang tepat untuk menguji suatu pendapat agar dapat diketahui kesalahan dan kekurangannya.

Ketika berpikir kritis seseorang akan sangat berusaha dengan kemampuannya agar apa yang akan dilakukan dan yang mereka pikirkan tersebut adalah benar. Menurut Molan (2012: 34) “berpikir kritis sebagai kemampuan berpikir jernih agar bisa sampai pada kebenaran sejati". Orang tersebut akan sangat yakin dan optimis bahwa apa yang dia katakan adalah benar. Seseorang yang berpikir kritis tidak hanya mengemukakan pendapatnya yang dianggap benar, tetapi juga dapat mengklaim atau merubah pendapat orang lain yang menurutnya tidak sesuai dengan pemikirannya. Menurut Moore dan Parker (2009: 1) dikatakan sebagai berikut: "critical thinking is the careful application of reason in the determination of the whether a claim is true. Notice that it is not so much coming up with claims, true or otherwise, that constitutes critical thinking, it is the evolution of claims". Dalam arti bebas, berpikir kritis adalah aplikasi untuk membuat sebuah alasan yang bersifat hati - hati dalam penentuan apakah pendapat itu adalah benar atau sebaliknya atau berpikir kritis itu adalah perubahan pendapat. Seorang pemikir yang kritis dapat menentukan kebenaran suatu pendapat atau sebaliknya, bahkan dapat juga merubah pendapat atau melengkapi suatu pendapat orang lain.

Dengan berpikir kritis seseorang tidak dapat mengambil suatu keputusan dengan tergesa-gesa karena keputusan yang diambil harus berdasarkan standar tertentu seperti yang diungkapkan oleh Fisher (2009: 13), "berpikir kritis adalah aktivitas terampil yang bisa dilakukan dengan lebih baik atau sebaliknya dan pemikiran kritis yang baik akan memenuhi beragam standar intelektual seperti kejelasan, relevansi, kecukupan, koherensi, dan lain-lain". Jika seseorang telah memiliki pemikiran yang kritis maka keputusan yang diambil orang tersebut akan jelas, relevan, dan cukup koheren. Seseorang yang aktif bertanya menunjukkan daya kekritisan orang tersebut, seperti pendapat Fakhruddin (2009: 52) yang menyatakan bahwa "pertanyaan yang kita ajukan menunjukkan daya kritis kita. Dengan bertanya, kita sedang mengkonstruksi pikiran dan hati kita, untuk menemukan sebuah solusi bijak yang bisa diaktualisasikan demi kemaslahatan dan kemanfaatan semua orang, bahkan demi kelestarian semesta ini". Dari uraian tersebut, aktif bertanya dapat dijadikan salah satu indikator kekritisan seseorang, karena ia ingin menggali semua informasi yang didapatinya sampai dengan sesuai menurutnya berdasarkan pemikiran yang rasional.

Jadi disimpulkan, berpikir kritis merupakan berpikir tingkat tinggi untuk menyampaikan suatu pendapat yang dianggap benar atau sebaliknya berdasarkan pemikiran dan alasan yang rasional dan dapat dipertanggungjawabkan dengan indikator dapat memilih strategi yang tepat, optimis, berani menyanggah, tidak mudah percaya, banyak bertanya, dan membuat kesimpulan.

\section{METODE PENELITIAN}

Penelitian ini termasuk jenis penelitian korelasional dengan pendekatan kuantitatif. Penelitian seperti ini disebut penelitian expost facto karena di dalam penelitian ini tidak dibuat perlakuan pada objek penelitian, melainkan hanya mengungkapkan fakta pada diri responden.

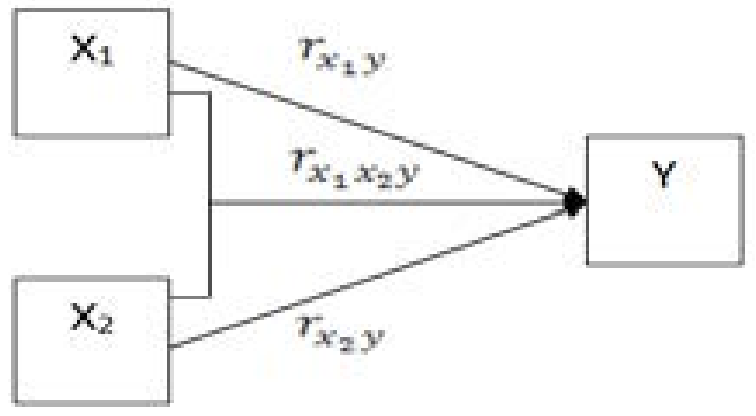

Gambar 2. Desain penelitian

Keterangan:

$\mathrm{X}_{1} \quad$ : Adversity Quotient (AQ)

$\mathrm{X}_{2} \quad$ : Kemampuan Berpikir Kritis

Y : Prestasi Belajar Matematika

Sampel dalam penelitian ini adalah 57 siswa kelas VIII tahun pelajaran 2012/2013 dari SMPN 251 Jakarta yang dilaksanakan pada bulan Maret hingga Juli 2013. Pengambilan sampel dilakukan secara acak yaitu dengan teknik random sampling. Penelitian ini menggunakan tiga buah instrumen yaitu instrumen adversity quotient $(A Q)$ dan instrumen kemampuan berpikir kritis yang didapat melalui metode kuesioner sedangkan instrumen prestasi belajar Matematika yang didapat melalui metode dokumentasi. Instrumen terlebih dahulu divalidasi secara empiris. Uji coba instrumen dilakukan di kelas lain yang tidak dijadikan sampel. Data dianalisis terlebih dahulu dengan uji persyaratan yaitu, uji normalitas, uji linieritas, dan uji multikolinieritas. Berdasarkan keterpenuhan kriteria 
dalam uji persyaratan analisis data, dilakukan analisis inferensial untuk pengujian hipotesis penelitian. Analisis inferensial menggunakan teknik analisis korelasi dan regresi berganda.

\section{HASIL DAN PEMBAHASAN}

Secara deskriptif data penelitian ini dinyatakan dalam tabel 1.

Tabel 1. Hasil Perhitungan Statistik Deskriptif

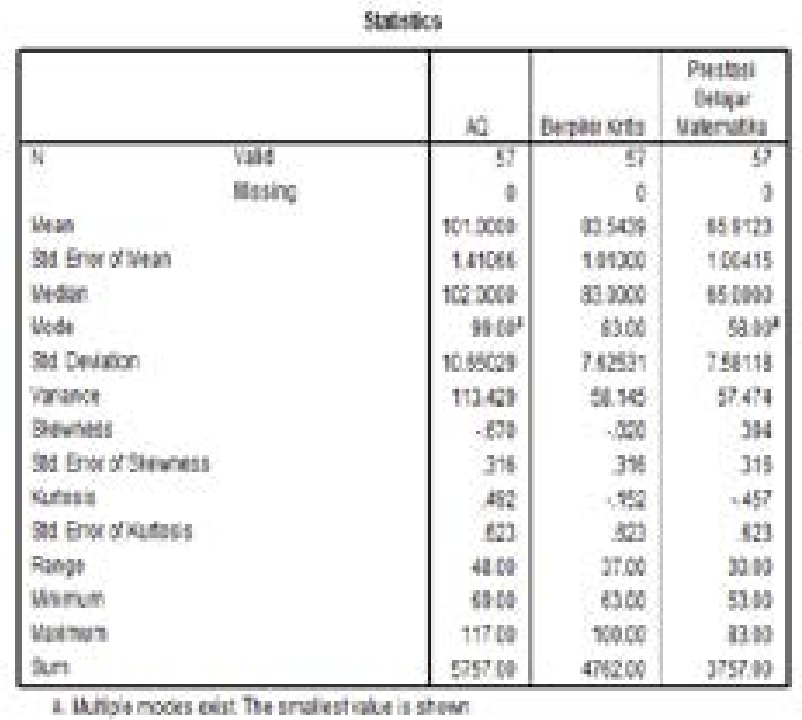

Sumber: Data primer yang diolah

Dari tabel 1, terlihat bahwa prestasi belajar matematika tergolong sedang. Hal ini terlihat dari nilai mean, median, dan modus yang nilainya masih agak jauh dari skor maksimum yang mungkin dicapai untuk variabel prestasi belajar matematika yaitu 100 . Adversity quotient tergolong tinggi, terlihat dari nilai mean, median, dan modus yang nilainya mendekati skor maksimum yang mungkin dicapai untuk variabel adversity quotient yaitu 130 . Terakhir, kemampuan berpikir kritis dapat dikatakan tinggi. Hal ini terlihat dari nilai mean, median, dan modus yang nilainya mendekati skor maksimum variabel kemampuan berpikir kritis yaitu 100

Selanjutnya, sebelum dilakukan pengujian hipotesis, terlebih dahulu harus dilakukan pengujian persyaratan analisis data yang meliputi uji normalitas, uji linieritas, dan uji multikolinieritas.

Pengujian normalitas dilakukan untuk mengetahui distribusi data untuk setiap variabel yang diteliti normal atau tidak. Pengujian dilakukan menggunakan uji Kolmogorov Smirnov, dengan kriteria data berdistribusi normal jika sig K. S. > 0,05. Hasil perhitungan ditunjukkan dalam tabel 2.
Tabel 2. Hasil Uji Normalitas

\begin{tabular}{|c|c|c|}
\hline \multicolumn{1}{|c|}{ Variabel } & Sig K. S. & Keterangan \\
\hline Adversity Quotient & 0,909 & Normal \\
\hline Kemampuan berpikir kritis & 0,747 & Normal \\
\hline Variabel & Sig K. S. & Keterangan \\
\hline Prestasi belajar matematika & 0,644 & Normal \\
\hline
\end{tabular}

Sumber: Data primer yang diolah

Pengujian linieritas menggunakan tabel bantuan ANOVA, dengan kriteria data berdistribusi normal jika sig deviation from linearity $>0,05$. Hasil perhitungan ditunjukkan melalui tabel 3 .

Tabel 3. Hasil Uji Linieritas

\begin{tabular}{|c|c|c|}
\hline Garis yang diuji & Sig & Keterangan \\
\hline $\mathrm{X} 1$ atas $\mathrm{Y}$ & 0,173 & Linier \\
\hline $\mathrm{X} 2$ atas $\mathrm{Y}$ & 0,148 & Linier \\
\hline
\end{tabular}

Sumber: Data primer yang diolah

Uji multikolinieritas menggunakan koefisien VIF (Variance inflation factor), dimaksudkan untuk menguji hubungan antar variabel bebas, yaitu ada tidaknya hubungan yang kuat antar variabel adversity quotient dan kemampuan berpikir kritis, dengan kriteria jika VIF $<10$ maka tidak terjadi multikolinieritas. Hasil perhitungan ditunjukkan dalam tabel 4 .

Tabel 4. Hasil Uji Multikolinieritas

\begin{tabular}{|c|c|l|}
\hline \multicolumn{1}{|c|}{ Variabel } & VIF & \multicolumn{1}{|c|}{ Keterangan } \\
\hline $\begin{array}{l}\text { AQ dan berpikir } \\
\text { kritis }\end{array}$ & 2,41 & $\begin{array}{l}\text { Tidak terjadi multi- } \\
\text { kolinieritas }\end{array}$ \\
\hline
\end{tabular}

Sumber: Data primer yang diolah

Setelah semua persyaratan analisis data terpenuhi, selanjutnya dilakukan pengujian hipotesis yaitu dengan teknik korelasi dan regresi ganda. Hasil perhitungan ditunjukkan melalui tabel 5, tabel 6, dan tabel 7.

Tabel 5. Hasil Perhitungan Koefisien Korelasi dan Koefisien Determinasi

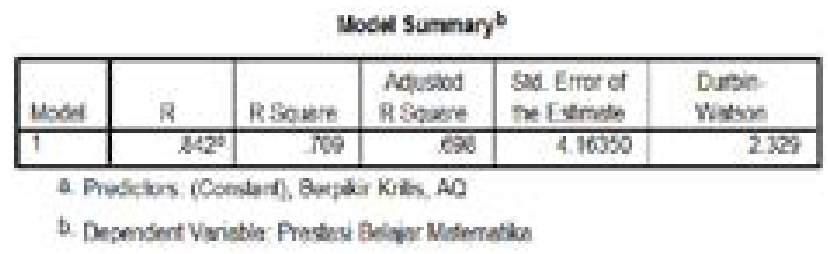

Tabel 6. Hasil Perhitungan Persamaan Regresi dan Signifikansi Regresi Tiap Variabel

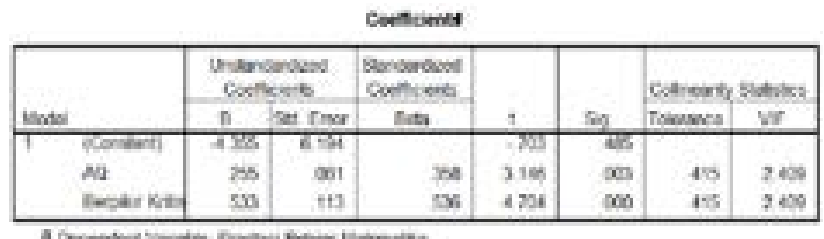

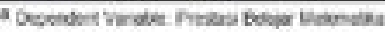


Tabel 7. Hasil Perhitungan Signifikansi Regresi Awover

\begin{tabular}{|c|c|c|c|c|c|c|}
\hline Howe & & $\begin{array}{l}S i m e \\
k\end{array}$ & it & Untares: & $y$ & ㄴy니 \\
\hline \multirow[t]{3}{*}{7} & Thombers & 1200650 & 2 & 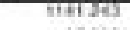 & Eका & $\infty 00$ \\
\hline & Pondost & wo one & $s$ & $t 2 x$ & & \\
\hline & tees & 2078501 & 36 & & & \\
\hline
\end{tabular}

Dari tabel 5 diperoleh koefisien korelasi sebesar 0,842; nilai ini menunjukkan ada korelasi yang sangat kuat antara adversity quotient dan kemampuan berpikir kritis secara bersama-sama terhadap prestasi belajar Matematika. Besar $\hat{Y}$ 'efisien determinasi 70,9\%, yang berarti $70,9 \%$ prestasi belajar matematika dipengaruhi oleh adversity quotient dan kemampuan berpikir kritis, sedangkan sisanya dipengaruhi oleh faktor lain yang tidak dibahas dalam penelitian ini.

Persamaan regresi (dalam tabel 6) yang terbentuk adalah $=-4,355+0,255 \mathrm{X}_{1}+0,533 \mathrm{X}_{2}$. Hal ini diartikan bahwa jika adversity quotient dan kemampuan berpikir kritis diabaikan, maka prestasi belajar -4,35; setiap penambahan 1 point pada adversity quotient akan menambah prestasi belajar Matematika sebesar 0,255; dan setiap penambahan 1 point pada kemampuan berpikir kritis akan menambah prestasi belajar Matematika sebesar 0,533. Hasil uji signifikansi koefisien regresi (dalam tabel 7) diperoleh nilai $\mathrm{F}_{\text {hitung }}$ =65,836; dengan signifikansi 0,000; sedangkan $\mathrm{F}_{\text {tabel }}$ $=3,17$; sehingga dapat disimpulkan bahwa koefisien regresi yang terbentuk signifikan, atau secara bersamasama adversity quotient dan kemampuan berpikir kritis memberi pengaruh positif dan signifikan terhadap prestasi belajar matematika.

Pengujian hipotesis parsial untuk masing-masing variabel terhadap variabel terikat menunjukkan bahwa secara individu variabel $A Q$ memiliki nilai $t_{\text {hitung }}$ $=3,146$ dengan signifikansi 0,003 $<0,05$; sehingga disimpulkan variabel $A Q$ memberikan pengaruh positif dan signifikan terhadap prestasi belajar matematika, sedangkan variabel kemampuan berpikir kritis memiliki nilai $\mathrm{t}_{\text {hitung }}=4,704$ dengan signifikansi 0,000 <0,05; sehingga disimpulkan variabel kemampuan berpikir kritis memberikan pengaruh positif dan signifikan terhadap prestasi belajar matematika.

\section{Pembahasan}

Dari hasil penelitian ini telah ditemukan bahwa Adversity Quotient $(A Q)$ dan kemampuan berpikir kritis memberikan pengaruh positif dan signifikan terhadap prestasi belajar Matematika siswa. Hal ini tentu saja diperoleh dari proses pembelajaran yang membangkitkan semangat juang siswa dan tentu saja terjadi interaksi yang positif dengan guru. Pembelajaran yang baik adalah pembelajaran dimana terjadi interaksi edukatif antara guru sebagai pengajar dan siswa sebagai subjek belajar. Sardiman (2011: 1) "Interaksi edukatif adalah interaksi yang berlangsung dalam suatu ikatan untuk tujuan pendidikan dan pengajaran". Dengan berlangsungnya interaksi edukatif ini, diharapkan potensi siswa sedikit demi sedikit dapat berkembang.

Dalam kegiatan pembelajaran tidak selamanya berjalan sesuai apa yang diharapkan, melainkan ada berbagai masalah yang timbul didalamnya. Proses pembelajaran diharapkan berjalan ideal, akan tetapi Leonard (2013: 60) mengatakan bahwa kondisi ideal tidak selalu terjadi dalam pembelajaran, justru proses pembelajaran menimbulkan kecemasan bagi peserta didik. Khususnya dalam mata pelajaran Matematika, seperti yang diungkapkan Fauziyah (2013: 78), "Matematika sangat berkaitan erat dengan masalah, sebagian besar ahli pendidikan Matematika menyatakan bahwa masalah merupakan pertanyaan yang harus dijawab atau direspon, tetapi mereka juga menyatakan bahwa tidak semua pertanyaan otomatis akan menjadi masalah". Jadi, semua tergantung dari sikap dan kemampuan berpikir yang dimiliki oleh masing-masing siswa. Sikap yang diambil siswa untuk mengatasi masalah tersebut tergantung dari seberapa baik adversity quotient yang dimiliki oleh siswa tersebut, sedangkan cara untuk memecahkan masalah tersebut tergantung dari seberapa baik kemampuan berpikir kritisnya. Dari data penelitian ini, terlihat bahwa mayoritas responden memiliki adversity quotient dan kemampuan berpikir yang cukup baik dan faktanya secara empiris berpengaruh positif terhadap prestasi belajar Matematikanya.

Adversity quotient yang dimiliki setiap siswa berbeda-beda seperti yang diungkapkan sebelumnya. Menurut Stoltz dan sekaligus pelopor study $A Q$ ini (Hans, 2006: 91) "Adversity Quotient adalah kegigihan dalam mengatasi segala rintangan dalam mendaki puncak sukses yang diinginkan", sehingga untuk mencapai suatu kesuksesan dibutuhkan adversity quotient. Kesuksesan yang hendak dicapai oleh seorang siswa yaitu prestasi belajar yang berkembang. Seseorang yang memiliki adversity quotient tinggi akan memiliki sifat tidak mudah menyerah dalam menghadapi kesulitan.

Meningkatkan kemampuan berpikir kritis dalam suatu pembelajaran dapat dilakukan dengan cara pemilihan model pembelajaran yang tepat di sekolah. Hal ini seperti yang diungkapkan oleh Apriani (2012: 820) "model pembelajaran IMPROVE dapat meningkatkan kemampuan berpikir kritis dan hasil belajar siswa karena dalam pembelajaran ini masing-masing langkahnya menekankan pada pembentukan pema- 
haman konsep siswa". Hal ini juga disebutkan dalam hasil penelitian Sarwi dan Khanafiyah (2010: 132), "kegiatan praktikum menggunakan alat peraga dapat meningkatkan keterampilan berpikir kritis". Syahbana juga mengungkapkan (2012: 53), “dengan pendekatan CTL dapat meningkatkan kemampuan berpikir kritis matematis siswa SMP Negeri 17 Palembang".

Berpikir kritis merupakan suatu proses berpikir tingkat tinggi sehingga dapat menghasilkan suatu keputusan dan pemikiran yang baik. Dengan indikator banyak bertanya, maka dapat membuat seseorang menjadi lebih banyak tahu dan memiliki wawasan yang luas. Wawasan inilah yang nantinya akan digunakan sebagai bahan pertimbangan untuk mengambil suatu keputusan dan pemikiran terbaik sebagai cara pemecahan masalah yang dihadapinya.

Dari penelitian ini ditemukan bahwa ternyata adversity quotient setiap siswa berbeda-beda, sehingga perlu adanya perlakuan berbeda kepada masingmasing siswa. Seperti yang dikemukakan dalam hasil penelitian Fauziyah (2013: 88), “siswa quitter tidak memiliki ketertarikan pada matematika, hendaknya guru mampu memberikan motivasi kepada siswa quitter, dan memberikan sisi lain yang menarik dalam matematika. Untuk siswa camper, guru dapat melakukan bimbingan dan memberikan semangat agar siswa tidak berhenti dan meninggalkan idenya begitu saja. Siswa climber telah memiliki semangat yang tinggi dalam menghadapi tantangan, tapi hendaknya guru tetap mendampingi siswa agar dapat mencapai hasil yang maksimal".

Selain itu penelitian ini juga telah membuktikan bahwa adversity quotient dan kemampuan berpikir kritis memberikan pengaruh dan manfaat yang besar terhadap pencapaian prestasi belajar Matematika. Selanjutnya, diharapkan ada penelitian-penelitian yang bertujuan mengembangkan peran adversity quotient dan kemampuan berpikir kritis, sehingga prestasi belajar Matematika siswa dapat mencapai hasil yang optimal.

\section{PENUTUP}

\section{Kesimpulan}

Berdasarkan hasil pengolahan data dan interprestasi hasil penelitian, penelitian ini telah berhasil menemukan dan menyimpulkan hal-hal sebagai berikut:

Ada pengaruh yang signifikan antara adversity quotient (AQ) dan kemampuan berpikir kritis secara bersama-sama terhadap prestasi belajar Matematika, yang diartikan semakin baik adversity quotient dan kemampuan berpikir kritis siswa, maka semakin baik prestasi belajar matematikanya.

Ada pengaruh yang signifikan antara Adversity Quotient (AQ) terhadap prestasi belajar Matematika, yang diartikan semakin baik adversity quotient siswa, maka semakin baik prestasi belajar matematikanya.

Ada pengaruh yang signifikan antara kemampuan berpikir kritis terhadap prestasi belajar Matematika, yang diartikan semakin baik kemampuan berpikir kritis siswa, maka semakin baik prestasi belajar matematikanya.

\section{Saran}

Dari kesimpulan penelitian ini, diharapkan seluruh elemen pendidikan seperti guru, kepala sekolah, dan siswa dalam proses pembelajaran harus memperhatikan adversity quotient (AQ) dan kemampuan berpikir kritis yang dimiliki siswa. Berikutnya, kepala sekolah sebaiknya memberikan dorongan kepada siswa agar memiliki Adversity Quotient (AQ) dan kemampuan berpikir kritis yang tinggi. Selain itu, membuat pelatihan-pelatihan kepada guru mengenai pengembangan Adversity Quotient (AQ) dan kemampuan berpikir kritis, sehingga dapat mengimplementasikannya kepada siswa. Di sisi lain, guru dapat memilih metode pembelajaran yang tepat, sehingga dapat meningkatkan Adversity Quotient (AQ) dan kemampuan berpikir kritis siswa, sedangkan siswa diharapkan dapat melatih diri untuk meningkatkan adversity quotient dengan cara menantang diri sendiri, dan membuat reward atau $a$ punishment sendiri.

\section{DAFTAR PUSTAKA}

Agustian, A. G. (2001). Rahasia sukses membangun kecerdasan emosi dan spiritual ESQ: Emotional quotient berdasarkan enam rukun iman dan lima rukun islam. Jakarta: Arga.

Apriani, N. N. D. (2012). Penerapan model pembelajaran IMPROVE pada mata pelajaran teknologi informasi dan komunikasi untuk meningkatkan kemampuan berpikir kritis dan hasil belajar siswa. Kumpulan Artikel Mahasiswa Pendidikan Teknik Informatika (KARMAPATI), 1 (4): 811-822 (http: / / www. pti-undiksha. com/karmapati/vol1no4/ 32. pdf) diunduh 28 Agustus 2013 pukul 10. 30.

Arifin, Z. (2009). Evaluasi pembelajaran. Bandung: PT Remaja Rosdakarya.

De Bono, E. (1992). Mengajar berpikir. Jakarta: Erlangga.

Ekasari, A. dan Hafizhoh,. (2009). Hubungan antara adversity quotient dan dukungan sosial dengan intensi untuk pulih dari ketergantungan narkotika alkohol psikotropika dan zat adiktif (napza) pada penderita 
di wilayah Bekasi Utara lembaga kasih Indonesia. Jurnal Soul, 2 (2): 108-136. Diunduh http: // www. ejournal-unisma. net/ojs/index. php/ soul/article/view/606/551 07/04/2013 19: 07.

Fakhruddin, A. U. (2009). Bertanyalah, bertanyalah. Yogyakarta: Gara Ilmu.

Fauziyah, dkk. (2013). Proses berpikir kreatif siswa kelas $x$ dalam memecahkan masalah geometri berdasarkan tahapan wallas ditinjau dari adversity quotient (AQ) siswa. Jurnal Pendidikan Matematika Solusi, 1 (1). (http: //jurnal. fkip. uns. ac. id/index. php/ matematika/article/viewFile/676/1083) Diunduh 10 april 2013.

Greendberg, J, et al. (2000). Behavior in organizations. New Jersey: Prentice Hall.

Fisher, A. (2009). Berpikir kritis: Sebuah pengantar. Jakarta: Erlangga.

Hans, J. Z. A. (2006). Strategi pengembangan diri. Jakarta: Personal Development Training.

Hassoubah, Z. I. (2008). Mengasah Pikiran Kreatif dan Kritis. Nuansa: Bandung.

Leonard dan Kusumaningsih, K. D. (2009). Pengaruh model pembelajaran kooperatif tipe team games tournament (TGT) terhadap peningkatan hasil belajar biologi pada konsep sistem pencernaan manusia. Jurnal Faktor Exacta, 2(1): 83-98.

Leonard. (2013). Peran kemampuan berpikir lateral dan positif terhadap prestasi belajar evaluasi pendidikan. Cakrawala Pendidikan 32(1): 54-63.

Leonard. (2012). Level of appreciation, self concept and positive thinking on mathematics learning achievement. The International Journal of Social Sciences, 6 (1): 10-17.

Madhi, J. (2009). Kreatif berpikir. Surakarta: Ziyad Visi Media.

Molan, B. (2012). Logika dan ilmu seni berpikir Kritis. Jakarta: PT Indeks.

Moore and Parker. (2009). Critical thinking. New York: Mc Graw-Hill Companies.

Nasution, A. H. (1980). Landasan matematika. Jakarta: Bhratara Karya Aksara.

Pranandari, K. (2008). Kecerdasan adversitas ditinjau dari pengatasan masalah berbasis permasalahan dan emosi pada orang tua tunggal wanita. Jurnal Psikologi, 1 (2): 128-121. Diunduh http: / / ejournal. gunadarma. ac. id/index. php / psiko/article/ view/287/231 31/03/2013 8: 27

Rahastyana, P. F. dan Rahmah, L. (2007). Kewirausahaan dalam kaitannya dengan adversity quotient dan emotional quotient. Jurnal Proyeksi, 5 (1): 52-64. Diunduh http: //fpsi. unissula. ac. id/index. php?option= comcontent\& 31/03/2013 8: 06

Sagitasari, D. (2010). Hubungan kreativitas dan gaya belajar terhadap prestasi belajar siswa SMP. Yogyakarta: UNY. Diunduh http: / / eprints. uny. ac. id/1618/1/FINAL. pdf 21/01/2012 12: 04.

Sardiman. (2011). Interaksi dan motivasi belajar mengajar. Jakarta: PT Raja Grafindo Persada.

Sarwi dan Khanafiyah. (2010). Pengembangan alat peraga gaya gesek untuk meningkatkan keterampilan berpikir kritis siswa SMA. Jurnal Pendidikan Fisika Indonesia, 6 (1): 128-132. Diunduh 07/10/2012 12: 43 (journal. unnes. ac. id/nju/index. php/ JPFI/article/download/1125/1045)

Subini, N. (2011). Rahasia gaya belajar orang besar. Jakarta: Javalitera.

Suriasumantri, J.S. (2005). Filsafat ilmu sebuah pengantar populer. Jakarta: Pustaka Sinar Harapan.

Sutarmo, S. V. (2012). Otak dan beberapa fungsinya. Jakarta: Fakultas Kedokteran UI.

Syah, M. (2010). Psikologi pendidikan dengan pendekatan baru. Bandung: PT. Remaja Rosdakarya.

Syahbana, A. (2012). Peningkatan kemampuan berpikir kritis matematis siswa smp melalui pendekatan contextual teaching and learning. Edumatica, 2 (1): 45-57. Diunduh 11/1/2013 pukul 20. 31 (http: / / online-journal. unja. ac. id/index. php/ edumatica/article/view/604 )

Wijaya, T. (2007). Hubungan adversity intelligence dengan intensi berwirausaha (studi empiris pada siswa SMKN 7 Yogyakarta). Jurnal Manajemen dan Kewirausahaan, 9 (2): 117-127. Diunduh http: //www. petra. ac. id/ puslit/journals/dir. php?DepartmentID=MAN 01/04/2013 11: 28.

Winkel, W. S. (1999). Psikologi pengajaran. Jakarta: Raja Grasindo Persada. 